\title{
Early weaning and concentrate supplementation strategies for lamb production on Tifton-85 pasture
}

\section{Cláudio José Araújo da Silva1, Sergio Rodrigo Fernandes², Marina Gabriela Berchiol da Silva ${ }^{3}$, Alda Lúcia Gomes Monteiro ${ }^{4}$, César Henrique Espírito Candal Poli ${ }^{5}$, Odilei Rogerio Prado", Concepta McMannus ${ }^{5}$, Susana Gilaverte ${ }^{6}$}

\author{
${ }_{1}$ Programa de Pós-Graduação em Ciências Veterinárias, Universidade Federal do Paraná, Curitiba-PR, Brasil. \\ 2 Programa de Pós-Graduação em Ciência Animal, Universidade Federal do Paraná, Palotina-PR, Brasil. \\ ${ }^{3}$ Departamento de Melhoramento e Nutrição Animal, Faculdade de Medicina Veterinária e Zootecnia, Universidade Estadual Paulista "Júlio de \\ Mesquita Filho", Botucatu-SP, Brasil. \\ ${ }^{4}$ Departamento de Zootecnia, Universidade Federal do Paraná, Curitiba-PR, Brasil. \\ ${ }^{5}$ Departamento de Zootecnia, Universidade Federal do Rio Grande do Sul, Porto Alegre-RS, Brasil. \\ ${ }^{6}$ Programa de Pós-Graduação em Agronomia, Universidade Federal do Paraná, Curitiba-PR, Brasil.
}

\begin{abstract}
The influence of early weaning and concentrate supplementation strategies on sward characteristics, forage chemical composition and lamb productivity were evaluated in four production systems on Tifton-85 pasture: suckling lambs not supplemented until slaughter; suckling lambs supplemented with concentrate in creep feeding until slaughter; early-weaned lambs not supplemented until slaughter; and early-weaned lambs supplemented with concentrate until slaughter. Structural, morphological and productive characteristics of pasture were measured. The forage was chemically analyzed to estimate its composition. Lambs average daily gain and productivity were calculated. Sward height, forage and morphological components mass were lower in systems without weaning. Forage production was higher in systems with supplementation. Higher levels of neutral and acid detergent fiber were observed in forage ingested by lambs in creep feeding and by weaned and unsupplemented lambs. Average daily gain was higher for lambs in creep feeding $(275 \mathrm{~g} / \mathrm{d})$ and lower for the weaned and unsupplemented animals $(57 \mathrm{~g} / \mathrm{d})$. Productivity was higher for weaned and supplemented lambs (21 kg lamb body weight, BW gain/ha/d). Lower productivity was observed in systems without supplementation ( $5 \mathrm{~kg}$ lamb BW gain/ha/d on average). Ewes modify the sward conditions improving the pasture characteristics and the quality of forage produced. Changes in sward conditions affect the chemical composition of forage ingested by lambs. Early weaning may be an alternative to maximize pasture utilization in small areas. Concentrate supplementation may increase lamb performance and productivity in grazing systems. If the objective is to improve lamb individual performance, creep feeding should be used.
\end{abstract}

Key Words: average daily gain, creep feeding, leaf:stem ratio, productivity, stocking rate

\section{Introduction}

The increasing demand for lamb meat has led to the development of high-productivity and profitable lamb meat production systems. Thus, the production of lambs in grazing systems should favor the economic and environmental sustainability of the activity. The increase in animal productivity in these production systems depends on adoption of strategies that maximize the use of physical, plant and animal resources, and on an efficient grazing management.

Early weaning (between 40 and 60 days of age for lambs) may be a strategy to increase productivity as well as

Received June 25, 2013 and accepted April 29, 2014. Corresponding author: claudiojaraujosilva@gmail.com

http://dx.doi.org/10.1590/S1516-35982014000800005

Copyright $@ 2014$ Sociedade Brasileira de Zootecnia. This is an Open Access article distributed under the terms of the Creative Commons Attribution Non-Commercial License, which permits unrestricted non-commercial use, distribution, and reproduction in any medium, provided the original work is properly cited. ensure that ewes have a greater period to rest and recover their body condition. Early-weaned lambs kept exclusively on pasture have carcasses that are usually not well-accepted by the market (Fernandes et al., 2008; Ribeiro et al., 2009; Fernandes et al., 2011). Even with adequate forage allowance on pasture, early-weaned lambs have shown limited performance caused by selective grazing strategy (Poli et al., 2009), post-weaning stress (Napolitano et al., 2008) and greater susceptibility to parasites (Miller and Horohov, 2006). Lambs reared in these conditions do not achieve weight and body condition suitable for slaughter between three and four months of age.

Concentrate supplementation may be offered to lambs in the post-weaning period or with the dam in reserved feeders (creep feeding) with the purpose of reducing the slaughter age. Individual performance and carcass traits of grazing lambs are positively affected by concentrate supplementation offered daily at levels equal to or higher than $20 \mathrm{~g} / \mathrm{kg}$ of their body weight (BW) (Carvalho et al., 2007). 
The quantity and quality of concentrate supplement offered may affect the forage intake by grazing animals. Substitution effects occur with the use of concentrate supplementation in grazing conditions, which reduce forage intake by the animals. In this condition, increased animal performance and pasture support capacity are observed, and these are the benefits of applying this strategy in lamb meat production systems (Clark and Woodward, 2007).

The objective of this study was to evaluate the influence of early weaning and concentrate supplementation strategies on sward characteristics, forage chemical composition and productivity of lambs on Tifton- 85 pastures.

\section{Material and Methods}

The experiment was carried out at Universidade Federal do Paraná (UFPR), located in Pinhais-PR $\left(25^{\circ} 25^{\prime}\right.$ South, $49^{\circ} 8^{\prime}$ West, and altitude of $\left.915 \mathrm{~m}\right)$. The climate at this region is temperate humid with temperate summer, characterized as Cfb by Köppen (1931). The soil is characterized as a Yellow-Red latosoil with clay texture and hilly relief (EMBRAPA, 1999).

Four production systems were established on pasture: suckling lambs not supplemented until slaughter; suckling lambs supplemented with concentrate in creep feeding until slaughter; early-weaned lambs not supplemented until slaughter; and early-weaned lambs supplemented with concentrate until slaughter.

The trial was accomplished in a randomized-block design with three replications and five lambs per replication. The paddocks were the experimental units and the lambs in test were the observation units. The blocks were defined based on ewe age, which differed $(\mathrm{P}<0.05)$ by six months for each block, averaging 4.5 years.

Sixty Suffolk lambs (36 females and 24 non-castrated males) were distributed into the systems according to sex, BW and type of birth (single or twin). Their distribution into the experimental units was uniform and characterized by three females and two non-castrated males, and by four twin lambs plus one single lamb per paddock. Body weight and the age of the lambs at the beginning of trial were $15.3 \pm 3.3 \mathrm{~kg}$ and $46 \pm 6$ days, respectively. The trial lasted 98 days and finished when lambs reached $144 \pm 7$ days of age on average in all systems.

The lambs were weaned at $46 \pm 6$ days of age and immediately allocated into the paddocks of the systems with weaning. Eighteen ewes with $4.4 \pm 1.3$ years of age and $92.4 \pm 8.2 \mathrm{~kg} \mathrm{BW}$ were allocated into paddocks of the systems without weaning. Three ewes were homogeneously distributed in each paddock according to age defined for each block and kept with their offspring during the trial period.

In the systems with supplementation, lambs received a protein-energy concentrate supplement at $20 \mathrm{~g} / \mathrm{kg} \mathrm{BW}$ on a dry-matter (DM) basis daily. The supplement was composed, in an as-fed basis, of $400 \mathrm{~g} / \mathrm{kg}$ soybean meal, $400 \mathrm{~g} / \mathrm{kg}$ ground corn grain, $150 \mathrm{~g} / \mathrm{kg}$ wheat bran, $20 \mathrm{~g} / \mathrm{kg}$ mineral supplement (Ovinophós ${ }^{\circledR}$ ), $25 \mathrm{~g} / \mathrm{kg}$ limestone, and $5 \mathrm{~g} / \mathrm{kg}$ sodium chloride. Concentrate was formulated to meet lamb requirements for $250-300 \mathrm{~g} / \mathrm{d}$ of average daily gain (ADG), according to NRC (2007).

Chemical analyses of the concentrate supplement were performed at the Laboratory of Animal Nutrition (UFPR) at the beginning, the middle and at the end of trial period (Table 1). Crude protein (CP), ether extract (EE), lignin (LIG), ash, calcium (Ca) and phosphorus (P) levels were determined according to the procedures described on AOAC (2005). The neutral detergent fiber (NDF) and acid detergent fiber (ADF) levels were determined according to Van Soest et al. (1991). The metabolizable energy (ME) level was calculated using the equations described by Weiss et al. (1992).

Supplemented lambs were fed concentrate from 15 days old. During the trial period the supplement was offered in the afternoon $(16.30 \mathrm{~h})$ to avoid or minimize the substitution effect of forage for concentrate according to Gibb et al. (2002). The adjustments of supplement offer were made in 21-day intervals based on the lamb weight after fasting (food and water for $12 \mathrm{~h}$ ). Collection and weighing of supplement leftovers were carried out daily to estimate the supplement daily intake per lamb.

The experimental area was characterized by a 1.5 ha Tifton-85 (Cynodon spp.) pasture divided into 12 paddocks: six paddocks with 0.15 ha for systems without weaning; and six paddocks with 0.10 ha for systems with weaning. The systems were evaluated during the usual period of production/finishing of lambs in Brazil (spring-summer

Table 1 - Mean levels of dry matter and nutritional composition of concentrate supplement offered to the lambs in the systems with supplementation

\begin{tabular}{lc}
\hline Composition & Protein-energy concentrate \\
\hline Dry matter (DM, g/kg as fed) & 881.5 \\
Crude protein (g/kg DM) & 254.7 \\
Ether extract (g/kg DM) & 31.7 \\
Neutral detergent fiber (g/kg DM) & 201.2 \\
Acid detergent fiber (g/kg DM) & 76.7 \\
Lignin (g/kg DM) & 10.9 \\
Ash (g/kg DM) & 76.6 \\
Calcium (g/kg DM) & 13.2 \\
Phosphorus (g/kg DM) & 6.2 \\
Metabolizable energy (Mcal/kg DM) & 3.04 \\
\hline
\end{tabular}


period) and while the Tifton- 85 pasture showed high forage production (Nov/2008 to Mar/2009).

The continuous grazing method was used with variable stocking rate according to the put-and-take technique (Mott and Lucas, 1952). Adjustments were made every 21 days to maintain forage allowance at $120 \mathrm{~g} \mathrm{DM} / \mathrm{kg} \mathrm{BW} / \mathrm{d}$ and maximize the animal performance (Hodgson, 1990). Animal BW per area was calculated considering the lambs BW on systems with weaning and the ewes plus lambs BW on systems without weaning. An animal unit (AU) was characterized by lamb and by ewe plus lamb in the systems with and without weaning, respectively. Extra animals maintained in similar grazing conditions to that of the test animals were added or removed from the paddocks to maintain the pre-established forage allowance.

Forage production was assessed every 21 days using the forage accumulation rate (FAR, $\mathrm{kg} \mathrm{DM} / \mathrm{ha} / \mathrm{d}$ ). Two grazing-exclusion cages per paddock were used to estimate FAR (Klingman et al., 1943). The FAR was calculated as the difference between total forage mass (TFM, $\mathrm{kg} \mathrm{DM} / \mathrm{ha}$ ) of samples harvested inside the cages and the TFM of samples harvested outside of the cages at the previous sampling date, divided by the number of days between evaluations (Campbell, 1966).

Structural characteristics of the pasture were evaluated every 21 days including sward height ( $\mathrm{SH}, \mathrm{cm}), \mathrm{TFM}$ and green forage mass (GFM, $\mathrm{kg} \mathrm{DM} / \mathrm{ha}$ ). The sward height was measured according to Barthram (1985) with 400 points/ha being measured, which corresponded to 60 points in the 0.15 ha paddocks and 40 points in the 0.10 ha paddocks. The TFM was estimated by harvesting three forage samples per paddock, cut close to the soil using a $0.1 \mathrm{~m}^{2}$ iron circle. Significant subsamples (about 75\%) were separated into green forage and dead/senescent material. These fractions were dried in a forced-air oven at $65{ }^{\circ} \mathrm{C}$ until constant weight (72 h) and the dry weight was used to calculate TFM and GFM.

Morphological characteristics of the pasture were obtained from minor subsamples (about $25 \%$ ) of the forage samples harvested to estimate TFM. The subsamples were separated into leafblades, stems plus sheaths, dead/senescent material and inflorescence fractions and dried separately in a forced-air oven at $65{ }^{\circ} \mathrm{C}$ until reaching constant weight $(72 \mathrm{~h})$. After the drying process, the fractions were weighed and the DM of these fractions was used to calculate the mass of morphological components expressed in $\mathrm{kg} \mathrm{DM} / \mathrm{ha}$ and the leaf:stem ratio of the pasture.

The chemical composition of the pasture and the forage potentially ingested by the lambs was evaluated at the beginning, the middle and the end of trial. The pasture chemical composition was estimated from forage samples harvested to estimate TFM. The chemical composition of the forage potentially ingested by the lambs was estimated in samples harvested by simulated grazing using the handplucking technique (Burns et al., 1989). In this case, one sample containing approximately $500 \mathrm{~g}$ of fresh forage was harvested per paddock. Samples were dried in a forced-air oven at $65^{\circ} \mathrm{C}$ until reaching constant weight. After the drying process, the samples were weighed to estimate the forage DM level and ground in a Wiley mill with a $1 \mathrm{~mm}$ sieve. Levels of CP, NDF, ADF, Ca, P and ME were determined with the same methods described for the chemical analysis of concentrate supplement.

The performance was assessed based on weights after fasting (food and water for $12 \mathrm{~h}$ ) at 46 and 144 days of age, which corresponds to weights at the beginning $\left(\mathrm{BW}_{\mathrm{I}}\right)$ and the end $\left(\mathrm{BW}_{\mathrm{F}}\right)$ of the trial, respectively. $\mathrm{ADG}(\mathrm{g} / \mathrm{d})$ was calculated using $\mathrm{BW}_{\mathrm{F}}$ minus $\mathrm{BW}_{\mathrm{I}}$, divided by the trial period (98 d). Lamb stocking rate (lambs/ha) and capacity (lamb BW/ha), and BW gain per area (kg BW/ha/d) were calculated based on the average lamb BW of $30 \mathrm{~kg}$.

Data were analyzed by ANOVA using the general linear model (GLM) procedure for randomized blocks in a $2 \times 2$ factorial arrangement, which made it possible to evaluate the effects of early weaning and concentrate supplementation on the studied variables. Means that showed significance $(\mathrm{P}<0.05)$ for interaction between the studied effects were compared by Tukey's test $(\mathrm{P}<0.05)$. Statistical analyses were performed using the SAEG (Sistema para Análises Estatísticas e Genéticas, version 9.1) statistical package

\section{Results}

Weaning modified the structural and morphological characteristics of Tifton- 85 pasture. Sward height, TFM and masses of leaf (LM), stem plus sheath (SSM) and dead/ senescent material (DSM) were lower $(\mathrm{P}<0.05)$ in the systems without weaning (Table 2). Concentrate supplementation influenced FAR, which was higher $(\mathrm{P}<0.05)$ in the systems with supplementation (119 kg DM/ha/d) compared with those without supplementation ( $86 \mathrm{~kg} \mathrm{DM} / \mathrm{ha} / \mathrm{d}$ ).

Interaction between weaning and supplementation $(\mathrm{P}<0.05)$ was observed for inflorescence mass (Table 3 ), which was lower in the system with weaning and without supplementation (28.3 kg DM/ha).

The pasture CP, NDF, ADF, Ca and P levels were not altered $(\mathrm{P}>0.05)$ by weaning or concentrate supplementation (Table 4). The pasture LIG level was slightly higher $(\mathrm{P}<0.05)$ in systems without weaning $(68.4 \mathrm{~g} / \mathrm{kg} \mathrm{DM})$ compared with the systems with weaning $(62.7 \mathrm{~g} / \mathrm{kg} \mathrm{DM})$. Although the 
Table 2 - Means and standard error of the mean (SEM) for structural, morphological and productive characteristics of Tifton-85 pasture in response to early weaning and concentrate supplementation strategies in lamb production systems

\begin{tabular}{|c|c|c|c|c|c|c|c|c|}
\hline \multirow{2}{*}{ Variables } & \multicolumn{2}{|c|}{ W } & \multicolumn{2}{|c|}{$\mathrm{S}$} & \multicolumn{3}{|c|}{ P-value } & \multirow{2}{*}{ SEM } \\
\hline & $\mathrm{W}_{0}$ & $\mathrm{~W}_{1}$ & $\mathrm{~S}_{0}$ & $\mathrm{~S}_{1}$ & W & $\mathrm{S}$ & $\mathrm{W} \times \mathrm{S}$ & \\
\hline $\mathrm{SH}(\mathrm{cm})$ & $13.3 b$ & $19.1 \mathrm{a}$ & 15.5 & 16.9 & 0.001 & 0.152 & 0.544 & 1.0 \\
\hline TFM (kg DM/ha) & $3430.2 b$ & $5139.0 \mathrm{a}$ & 4167.2 & 4402.0 & $<0.001$ & 0.348 & 0.753 & 276.3 \\
\hline FAR (kg DM/ha/d) & 96.3 & 108.8 & $85.9 \mathrm{~B}$ & $119.3 \mathrm{~A}$ & 0.318 & 0.027 & 0.085 & 8.7 \\
\hline LM (kg DM/ha) & $1043.0 \mathrm{~b}$ & $1482.5 \mathrm{a}$ & 1242.7 & 1282.8 & 0.001 & 0.575 & 0.681 & 73.7 \\
\hline SSM (kg DM/ha) & $1528.3 b$ & $2544.1 \mathrm{a}$ & 1966.8 & 2105.6 & $<0.001$ & 0.273 & 0.469 & 162.6 \\
\hline DSM (kg DM/ha) & $800.8 b$ & $1055.1 \mathrm{a}$ & 890.4 & 965.5 & 0.034 & 0.451 & 0.577 & 55.7 \\
\hline
\end{tabular}

SH - sward height; TFM - total forage mass; FAR - forage accumulation rate; LM - leaf mass; SSM - stem plus sheath mass; DSM - dead/senescent material; L:S - leaf:stem ratio.

$\mathrm{W}$ - weaning; $\mathrm{S}$ - supplementation; $\mathrm{W}_{0}$ - non-weaned; $\mathrm{W}_{1}$ - weaned; $\mathrm{S}_{0}$ - unsupplemented; $\mathrm{S}_{1}$ - supplemented; $\mathrm{W}, \mathrm{S}$ and $\mathrm{W} \times \mathrm{S}$ - effects of weaning, supplementation and their interaction, respectively.

a, $b$ - lowercase letters in the same row show difference by Tukey's test $(\mathrm{P}<0.05)$ between systems with or without weaning; A, B - uppercase letters in the same row show difference by Tukey's test $(\mathrm{P}<0.05)$ between systems with or without supplementation.

Table 3 - Mean and standard error of the mean (SEM) for inflorescence mass of Tifton- 85 in response to early weaning and concentrate supplementation strategies in lamb production systems

\begin{tabular}{|c|c|c|c|c|c|c|c|}
\hline \multirow{2}{*}{ Variables } & \multirow{2}{*}{ W } & \multicolumn{2}{|c|}{$\mathrm{S}$} & \multicolumn{3}{|c|}{ P-value } & \multirow{2}{*}{ SEM } \\
\hline & & $\mathrm{S}_{0}$ & $\mathrm{~S}_{1}$ & $\mathrm{~W}$ & $\mathrm{~S}$ & $\mathrm{~W} \times \mathrm{S}$ & \\
\hline Inflorescence mass (kg DM/ha) & $\mathrm{W}_{0}$ & $48.5 \mathrm{bA}$ & $67.8 \mathrm{aA}$ & 0.936 & 0.125 & 0.012 & 7.7 \\
\hline
\end{tabular}

$\mathrm{W}$ - weaning; S - supplementation; $\mathrm{W}_{0}$ - non-weaned; $\mathrm{W}_{1}$ - weaned; $\mathrm{S}_{0}$ - unsupplemented; $\mathrm{S}_{1}$ - supplemented; $\mathrm{W}, \mathrm{S}$ and $\mathrm{W} \times \mathrm{S}$ - effects of weaning, supplementation and their interaction, respectively.

Means followed by different lowercase letters in the same column and different uppercase letters in the same row show difference by Tukey's test ( $\mathrm{P}<0.05$ ).

Table 4 - Means and standard error of the mean (SEM) for nutritional composition of Tifton-85 in response to early weaning and concentrate supplementation strategies in lamb production systems

\begin{tabular}{|c|c|c|c|c|c|c|c|c|}
\hline \multirow{2}{*}{ Variables } & \multicolumn{2}{|c|}{ W } & \multicolumn{2}{|c|}{$\mathrm{S}$} & \multicolumn{3}{|c|}{ P-value } & \multirow{2}{*}{ SEM } \\
\hline & $\mathrm{W}_{0}$ & $\mathrm{~W}_{1}$ & $\mathrm{~S}_{0}$ & $\mathrm{~S}_{1}$ & W & $\mathrm{S}$ & $\mathrm{W} \times \mathrm{S}$ & \\
\hline $\mathrm{DM}$ (g/kg as fed) & 261.5 & 268.5 & 268.2 & 261.8 & 0.367 & 0.399 & 0.788 & 4.5 \\
\hline $\mathrm{CP}(\mathrm{g} / \mathrm{kg} \mathrm{DM})$ & 160.0 & 165.0 & 159.8 & 165.2 & 0.529 & 0.503 & 0.720 & 3.8 \\
\hline NDF (g/kg DM) & 726.8 & 720.9 & 725.8 & 721.8 & 0.322 & 0.488 & 0.061 & 2.7 \\
\hline ADF (g/kg DM) & 332.8 & 338.0 & 336.2 & 334.6 & 0.294 & 0.730 & 0.065 & 2.3 \\
\hline LIG (g/kg DM) & $68.4 \mathrm{a}$ & $62.7 b$ & 67.4 & 63.8 & 0.046 & 0.168 & 0.059 & 1.1 \\
\hline $\mathrm{Ca}(\mathrm{g} / \mathrm{kg} \mathrm{DM})$ & 4.4 & 4.9 & 4.5 & 4.8 & 0.274 & 0.349 & 0.916 & 0.2 \\
\hline $\mathrm{P}(\mathrm{g} / \mathrm{kg} \mathrm{DM})$ & 4.9 & 5.1 & 5.0 & 5.0 & 0.357 & 0.952 & 0.702 & 0.1 \\
\hline ME (Mcal/kg DM) & 1.881 & 1.897 & $1.874 \mathrm{~B}$ & $1.904 \mathrm{~A}$ & 0.284 & 0.036 & 0.153 & 0.046 \\
\hline
\end{tabular}

DM - dry matter; CP - crude protein; NDF - neutral detergent fiber; ADF - acid detergent fiber; LIG - lignin; Ca - calcium; P - phosphorus; ME - metabolizable energy.

$\mathrm{W}$ - weaning; S - supplementation; $\mathrm{W}_{0}$ - non-weaned, $\mathrm{W}_{1}$ - weaned, $\mathrm{S}_{0}$ - unsupplemented, $\mathrm{S}_{1}$ - supplemented; $\mathrm{W}, \mathrm{S}$ and $\mathrm{W} \times \mathrm{S}$ - effects of weaning, supplementation and their interaction, respectively.

$\mathrm{a}, \mathrm{b}$ - lowercase letters in the same row show difference by Tukey's test $(\mathrm{P}<0.05)$ between systems with or without weaning; A, B - uppercase letters in the same row show difference by Tukey's test $(\mathrm{P}<0.05)$ between systems with or without supplementation.

morphological characteristics of the pasture were affected by weaning (Table 2), the higher proportions of stems $(2,544 \mathrm{~kg} \mathrm{DM} / \mathrm{ha})$ and lower leaf:stem ratio (0.58) did not reduce the forage nutritional composition in the systems with weaning compared with the systems without weaning $(\mathrm{SSM}=1,528 \mathrm{~kg} \mathrm{DM} / \mathrm{ha}$ and leaf:stem ratio =0.69). The pastures of systems with supplementation showed $\mathrm{ME}$ $1.6 \%$ higher than the systems without supplementation (1.87 Mcal kg/DM vs. $1.90 \mathrm{Mcal} / \mathrm{kg}$ DM; Table 4).

The levels of LIG, Ca, P, and ME of forage potentially ingested by lambs were not affected $(\mathrm{P}>0.05)$ by weaning or concentrate supplementation and showed mean values of $33.9 \mathrm{~g} / \mathrm{kg} \mathrm{DM} \mathrm{LIG}, 5.8 \mathrm{~g} / \mathrm{kg}$ DM Ca, $5.6 \mathrm{~g} / \mathrm{kg} \mathrm{DM} \mathrm{P}$, and
2.34 Mcal/kg DM ME. Interaction between weaning and supplementation $(\mathrm{P}<0.05)$ was observed for $\mathrm{CP}, \mathrm{NDF}$ and ADF levels of forage potentially ingested by lambs (Table 5). The forage ingested by weaned and unsupplemented lambs showed a lower CP level (189 g/kg DM) compared with the other systems (average $229 \mathrm{~g} / \mathrm{kg} \mathrm{DM}$ ). Lambs in creep feeding and weaned and unsupplemented lambs ingested forage with higher NDF and ADF levels compared with the other systems, with mean values of 717 and $299 \mathrm{~g} / \mathrm{kg} \mathrm{DM}$, respectively.

Interaction between weaning and supplementation $(\mathrm{P}<0.05)$ was observed for lamb individual performance (Table 6). Weaning reduced ADG by $78 \mathrm{~g} / \mathrm{d}$ for 
Table 5 - Mean and standard error of the mean (SEM) for the levels of chemical components of forage potentially ingested by lambs (collected by simulated grazing) in Tifton- 85 pasture in response to early weaning and concentrate supplementation strategies in lamb production systems

\begin{tabular}{|c|c|c|c|c|c|c|c|}
\hline \multirow{2}{*}{ Variables } & \multirow{2}{*}{$\mathrm{W}$} & \multicolumn{2}{|c|}{$\mathrm{S}$} & \multicolumn{3}{|c|}{ P-value } & \multirow{2}{*}{ SEM } \\
\hline & & $\mathrm{S}_{0}$ & $\mathrm{~S}_{1}$ & $\mathrm{~W}$ & $\mathrm{~S}$ & $\mathrm{~W} \times \mathrm{S}$ & \\
\hline \multirow{2}{*}{ Dry matter (g/kg as fed) } & $\mathrm{W}_{0}$ & $258.5 \mathrm{bA}$ & $277.5 \mathrm{aA}$ & \multirow{2}{*}{0.084} & \multirow{2}{*}{0.862} & \multirow{2}{*}{0.026} & \multirow{2}{*}{4.1} \\
\hline & $\mathrm{W}_{1}$ & $289.0 \mathrm{aA}$ & $272.2 \mathrm{aA}$ & & & & \\
\hline \multirow{2}{*}{ Crude protein (g/kg DM) } & $\mathrm{W}_{0}$ & $232.7 \mathrm{aA}$ & $216.3 \mathrm{aA}$ & \multirow{2}{*}{0.212} & \multirow{2}{*}{0.113} & \multirow{2}{*}{0.009} & \multirow{2}{*}{4.2} \\
\hline & $\mathrm{W}_{1}$ & $188.9 \mathrm{bB}$ & $236.6 \mathrm{aA}$ & & & & \\
\hline \multirow{2}{*}{ Neutral detergent fiber $(\mathrm{g} / \mathrm{kg} \mathrm{DM})$} & $\mathrm{W}_{0}$ & $691.0 \mathrm{bB}$ & $715.3 \mathrm{aA}$ & \multirow{2}{*}{0.768} & \multirow{2}{*}{0.755} & \multirow{2}{*}{0.007} & \multirow{2}{*}{3.4} \\
\hline & $\mathrm{W}_{1}$ & $719.5 \mathrm{aA}$ & $690.9 \mathrm{bB}$ & & & & \\
\hline \multirow{2}{*}{ Acid detergent fiber (g/kg DM) } & $\mathrm{W}_{0}$ & $281.3 \mathrm{bB}$ & $299.4 \mathrm{aA}$ & \multirow{2}{*}{0.910} & \multirow{2}{*}{0.843} & \multirow{2}{*}{0.002} & \multirow{2}{*}{1.7} \\
\hline & $\mathrm{W}_{1}$ & $299.1 \mathrm{aA}$ & $282.4 \mathrm{bB}$ & & & & \\
\hline
\end{tabular}

$\mathrm{W}$ - weaning; S - supplementation; $\mathrm{W}_{0}$ - non-weaned, $\mathrm{W}_{1}$ - weaned, $\mathrm{S}_{0}$ - unsupplemented, $\mathrm{S}_{1}$ - supplemented; $\mathrm{W}, \mathrm{S}$ and $\mathrm{W} \times \mathrm{S}-$ effects of weaning, supplementation and their interaction, respectively.

$\mathrm{a}, \mathrm{b}$ - lowercase letters in the same row show difference by Tukey's test $(\mathrm{P}<0.05)$ between systems with or without weaning; A, B - uppercase letters in the same row show difference by Tukey's test $(\mathrm{P}<0.05)$ between systems with or without supplementation.

Table 6 - Means and standard error of the mean (SEM) for individual and area performance of lambs in response to early weaning and concentrate supplementation strategies in lamb production systems

\begin{tabular}{|c|c|c|c|c|c|c|c|}
\hline \multirow{2}{*}{ Variables } & \multirow{2}{*}{$\mathrm{W}$} & \multicolumn{2}{|c|}{$\mathrm{S}$} & \multicolumn{3}{|c|}{ P-value } & \multirow{2}{*}{ SEM } \\
\hline & & $\mathrm{S}_{0}$ & $\mathrm{~S}_{1}$ & $\mathrm{~W}$ & $\mathrm{~S}$ & $\mathrm{~W} \times \mathrm{S}$ & \\
\hline \multirow{2}{*}{ Stocking rate (lambs/ha) } & $\mathrm{W}_{0}$ & $33 \mathrm{bA}$ & $34 \mathrm{bA}$ & \multirow{2}{*}{$<0.001$} & \multirow{2}{*}{0.009} & \multirow{2}{*}{0.013} & \multirow{2}{*}{13} \\
\hline & $\mathrm{w}_{1}$ & $100 \mathrm{aB}$ & $134 \mathrm{aA}$ & & & & \\
\hline \multirow{2}{*}{ Stocking capacity (lamb BW/ha) } & $\mathrm{W}_{0}$ & $713 \mathrm{bA}$ & $900 \mathrm{bA}$ & \multirow{2}{*}{$<0.001$} & \multirow{2}{*}{$<0.001$} & \multirow{2}{*}{0.002} & \multirow{2}{*}{318} \\
\hline & $\mathrm{W}_{1}$ & $1,961 \mathrm{aB}$ & $3,336 \mathrm{aA}$ & & & & \\
\hline \multirow{2}{*}{ Average daily gain (g/d) } & $\mathrm{W}_{0}$ & $135 \mathrm{aB}$ & $275 \mathrm{aA}$ & \multirow{2}{*}{$<0.001$} & \multirow{2}{*}{$<0.001$} & \multirow{2}{*}{0.002} & \multirow{2}{*}{20} \\
\hline & $\mathrm{W}_{1}$ & $57 \mathrm{bB}$ & $158 \mathrm{bA}$ & & & & \\
\hline \multirow{2}{*}{ BW gain per area $(\mathrm{kg} \mathrm{BW} / \mathrm{ha} / \mathrm{d})$} & $\mathrm{W}_{0}$ & $4.38 \mathrm{aB}$ & $9.43 \mathrm{bA}$ & \multirow{2}{*}{$<0.001$} & \multirow{2}{*}{$<0.001$} & \multirow{2}{*}{$<0.001$} & \multirow{2}{*}{2.03} \\
\hline & $\mathrm{W}_{1}$ & $5.68 \mathrm{aB}$ & $21.25 \mathrm{aA}$ & & & & \\
\hline
\end{tabular}

$\mathrm{W}$ - weaning; $\mathrm{S}$ - supplementation; $\mathrm{W}_{0}$ - non-weaned; $\mathrm{W}_{1}$ - weaned; $\mathrm{S}_{0}$ - unsupplemented; $\mathrm{S}_{1}$ - supplemented; $\mathrm{W}, \mathrm{S}$ and $\mathrm{W} \times \mathrm{S}$ - effects of weaning, supplementation and their interaction, respectively.

$\mathrm{a}, \mathrm{b}$ - lowercase letters in the same row show difference by Tukey's test $(\mathrm{P}<0.05)$ between systems with or without weaning; A, B - uppercase letters in the same row show difference by Tukey's test $(\mathrm{P}<0.05)$ between systems with or without supplementation.

unsupplemented lambs and by $117 \mathrm{~g} / \mathrm{d}$ for the supplemented animals. Concentrate supplementation increased ADG by $140 \mathrm{~g} / \mathrm{d}$ for suckling lambs and by $101 \mathrm{~g} / \mathrm{d}$ for weaned lambs. The average daily gain was higher for lambs in creep feeding $(275 \mathrm{~g} / \mathrm{d})$ and lower for weaned and unsupplemented lambs $(57 \mathrm{~g} / \mathrm{d})$.

Weaning increased $(\mathrm{P}<0.05)$ lamb stocking rate by 67 and 100 lambs/ha in systems without and with supplementation, respectively (Table 6). Hence, the pasture stocking capacity increased $(\mathrm{P}<0.05)$ by 1,248 and 2,436 $\mathrm{kg}$ lamb $\mathrm{BW} / \mathrm{ha}$ in weaned systems without and with supplementation, respectively. Weaning did not affect $(\mathrm{P}>0.05)$ lamb BW gain per area in systems without supplementation, averaging $5 \mathrm{~kg}$ lamb BW/ha/d. However, weaning increased $(\mathrm{P}<0.05)$ lamb BW gain per area by $12 \mathrm{~kg}$ lamb BW/ha/d in systems with supplementation.

Concentrate supplementation increased $(\mathrm{P}<0.05)$ stocking rate, pasture stocking capacity and lamb BW gain per area in the system with weaning (Table 6). Stocking rate was increased by 34 lambs/ha and pasture stocking capacity was increased by $1,375 \mathrm{~kg}$ lamb BW/ha in response to supplementation in systems with weaning. The higher ADG of lambs supplemented post-weaning compared with the weaned and unsupplemented lambs resulted in increase $(\mathrm{P}<0.05)$ in lamb BW gain per area by approximately $16 \mathrm{~kg}$ lamb BW/ha/d. Concentrate supplementation did not affect $(\mathrm{P}<0.05)$ the stocking rate or pasture stocking capacity in systems without weaning, but the higher ADG of lambs in creep feeding determined an increase in lamb BW gain per area of $5 \mathrm{~kg}$ lamb BW/ha/d.

\section{Discussion}

The presence of ewes in the production systems led to the modification of sward characteristics (Table 2). The pasture showed lower SH and TFM in the systems 
without weaning compared with the systems with weaning. Moreover, the sward in the systems without weaning showed lower proportions of stems and higher L:S ratios. Differences in the sward characteristics may be caused by different grazing strategies used by lambs and ewes. Baumont et al. (2000) described that the lack of grazing experience of lamb results in increase in the time spent to select diets, reducing the intake rate and causing alterations in the sward characteristics when grazed exclusively by this type of animal.

Mean values for TFM and LM (Table 2) for all systems evaluated were within the expectation for sheep production. Silva et al. (2012) reported that a minimum cover ranging from 2,500 to 3,000 $\mathrm{kg} \mathrm{DM} /$ ha of Tifton 85 is recommended for growing lambs reared in the South Region of Brazil. Rattray et al. (1987) recommended that the LM must be maintained equal to or above $1,000 \mathrm{~kg} \mathrm{DM} / \mathrm{ha}$ not to limit the forage intake by grazing animals. In the present study, animals could select their diets without intake restriction.

Higher FAR in the systems with supplementation (Table 2) may have resulted from the reduced intake of forage by lambs, which is probably related to the substitutive effect of forage for concentrate in grazing condition. According to Camargo et al. (2009), the increase in concentrate supplementation levels for grazing lambs led to an increase in the FAR on pasture.

Indeed, when a supplement is provided the forage intake from the pasture may increase, remain the same, or even decrease. The associative responses between supplement and pasture may be determined by the quantity and quality of available forage, the characteristics and the manner of providing the supplement, and the production potential of the animals (Hodgson, 1990; Moore et al., 1999). It is noteworthy that when the balance of concentrated feed supplementation for grazing animals is achieved, the associative effects (additive or substitutive) are almost never considered. Thus, the identification of these factors may be important, especially to prevent changes in the forage:concentrate ratio, due to reduced intake of forage which in turn can modify the characteristics of the pasture and bring dietary imbalances and consequently affect the animal performance.

The higher lamb stocking rate in the system with weaning and supplementation (Table 6) may have reduced the inflorescence mass of pasture (Table 3) compared with the other systems. As previously mentioned, this is related to the substitutive effect that occurred in the systems with supplementation. However, this effect certainly provided an increase in lamb stocking capacity in these systems, leading to an increase in the stocking rate, which justify the lower amount of inflorescences in the pasture due to the possibility to keep the pasture in vegetative stage for a longer period with high stocking rates. In fact, higher stocking rates determine an increase in defoliation and interrupt the flowering process of the grasses, which remain in vegetative stage for a longer period (Hodgson, 1990).

The longer period that the pasture remained in vegetative stage in the system with weaning and supplementation determined an increase in the energy level of the pasture (Table 4). The forage ME level is positively correlated with its digestibility, which is significantly reduced when pasture reaches the reproductive stage due to an increase in the level of structural carbohydrates and degree of lignification in the flowering plant (Hodgson, 1990).

Differences between morphological composition and phenological stage of the pasture affected the nutritional composition of forage ingested by lambs (Table 5). Increase in NDF and ADF levels is associated with the higher proportion of inflorescences and increase in the mature: young leaf ratio, which may determine the reduction in the CP level of the forage ingested by the animals (Paciullo et al., 2001).

Comparing the nutritional composition of ingested forage with the nutritional requirements of the animals it can be seen that the pasture may integrally meet the daily $\mathrm{DM}, \mathrm{CP}$ and $\mathrm{ME}$ requirements for maximum performance of meat lambs (NRC, 2007). The elevated proportion of leaves in the diet increased the CP and ME levels of ingested forage, which were 34.5 and $24.0 \%$ higher than the levels observed on pasture, respectively (Table 5). The offer of good-quality pasture allowed for the intake of a highly nutritive diet by the lambs, characterized by high proportion of leaves, as well as adequate protein and energy to meet their nutritional requirements (NRC, 2007).

Lower individual performance was observed for weaned and unsupplemented lambs (Table 6). Similar results were reported by Carvalho et al. (2007) and Ribeiro et al. (2009) for early-weaned lambs kept on Tifton-85 and annual ryegrass pasture, respectively. An important factor which determines the low performance of weaned lambs was the restriction of milk intake. Evaluating the behavior of lambs used in this study, Silva et al. (2011) described that weaned lambs increased the grazing time to compensate the lack of milk in their diet. Nevertheless, this was not sufficient to supply the lack of milk and resulted in lower ADG for weaned lambs.

Concentrate supplementation was offered from 15 days of age for supplemented lambs, which may have influenced the positive individual performance results for these animals (Table 6). Ribeiro et al. (2009) observed 
similar ADG between suckling lambs supplemented or not with concentrate in creep feeding on ryegrass (Lolium multiflorum Lam.) pasture (294 vs. $303 \mathrm{~g} / \mathrm{d}$, respectively). However, these authors used concentrate supplementation at $10 \mathrm{~g} \mathrm{DM} / \mathrm{kg} \mathrm{BW/d}$ provided to the lambs from 40 days of age.

The concentrate supplementation provided to weaned lambs was sufficient to substitute milk in the diet, increasing ADG by approximately 2.8 times (57 to $158 \mathrm{~g} / \mathrm{d}$; Table 6 ). The post-weaning stress characterized by abrupt changes in the lamb nutritional condition, particularly by lack of milk, can be overcome with high-quality feeding provided in adequate amounts for grazing lambs (Bernardi et al., 2005). Even under a good grazing condition, characterized by a sward with high LM (Table 2) and high nutritional quality (Tables 4 and 5), the Tifton- 85 pasture did not meet the nutritional requirements of weaned lambs. Thus, supplementation with $20 \mathrm{~g} \mathrm{DM} / \mathrm{kg} \mathrm{BW} / \mathrm{d}$ of protein-energy concentrate may be an interesting alternative for earlyweaned lambs to achieve a high ADG and, therefore, better slaughter weights on grazing systems. Carvalho et al. (2007) and Fernandes et al. (2011) reported increase in slaughter weight and improvement of carcass traits of lambs in response to the concentrate supplementation under grazing condition.

The higher productivity observed for lambs supplemented post-weaning was related to the substitution effect of forage for concentrate, as reported by Silva et al. (2011). However this substitution effect was not observed for lambs in creep feeding. The low forage intake by lambs compared with the ewes determined similar stocking rate and pasture stocking capacity between systems without weaning.

The lamb ADG values (Table 6) were close those reported by Ribeiro et al. (2009) in similar grazing systems. However, the stocking rates (33 to $134 \mathrm{lamb} / \mathrm{ha}$ ) and lamb BW gain per area (4 to $21 \mathrm{~kg}$ lamb BW/ha/d) were higher than those found by these authors. In this way, higher stocking rates and productivity may be related to the intensity of pasture utilization. Ribeiro et al. (2009) used a low-intensity grazing management with $\mathrm{SH}$ ranging from 17.5 to $21.0 \mathrm{~cm}$ and TFM ranging from 2,815 to $2,987 \mathrm{~kg} \mathrm{DM} /$ ha on ryegrass pasture. These sward conditions were maintained with low lamb stocking rates ( 8 to 31 lambs/ha), which determined low productivity ( 2 to $4 \mathrm{~kg}$ lamb BW/ha/d). However, highintensity grazing management with variations in $\mathrm{SH}(13.3$ to $19.1 \mathrm{~cm})$ and TFM (3,430 to $5,139 \mathrm{~kg} \mathrm{DM} / \mathrm{ha}$ ) (Table 2) provided high lamb stocking rates and productivity on Tifton 85 pasture.

The low ADG for weaned and unsupplemented lambs was compensated by high stocking rate and resulted in productivity similar to that of unsupplemented suckling lambs (Table 6). The productivity of early-weaned lambs may be strongly increased by concentrate supplementation provided during the post-weaning period. This is a viable strategy to remove the ewes from the system without reducing lambs ADG by the lack of milk, and increasing the lamb stocking rate on pasture. Ewes removed from systems with supplementation may be allocated to grazing areas with low forage availability and quality, as recommended for dry ewes in maintenance (NRC, 2007). The use of concentrate supplementation for grazing lambs may be an alternative for accelerated lambing systems.

\section{Conclusions}

Maintaining the lambs with their dams is important to modifying the structural and morphological characteristics of the sward. The presence of ewes in lamb production systems is important to improving the qualitative components of the pasture. Concentrate supplementation allows for higher forage production on pasture. Differences in the sward structure affect the nutritional composition of the forage potentially ingested by lambs. Early weaning may be a viable alternative to maximize pasture use in small areas. Concentrate supplementation should be used to increase lamb performance and productivity in grazing systems. If the objective is to improve lamb individual performance, creep feeding should be used.

\section{References}

AOAC - Association of Official Analytical Chemists. 2005. Official methods of analysis. 18th ed. AOAC, Maryland.

Barthram, G. T. 1985. Experimental techniques: the HFRO sward stick. p.29-30. In: The Hill Farming Research Organization Biennial Report 1984/1985. HFRO, Penicuik.

Baumont, R.; Prache, S.; Meuret and Morand-Fehr, P. 2000. How forage characteristics influence behaviour and intake in small ruminants: a review. Livestock Production Science 64:15-28.

Bernardi, J. R. A.; Alves, J. B. and Marin, C. M. 2005. Desempenho de cordeiros sob quatro sistemas de produção. Revista Brasileira de Zootecnia 34:1248-1255.

Burns, J. C.; Lippke, H. and Fisher, D. S. 1989. The relationship of herbage mass and characteristics to animal responses in grazing experiments. p.7-20. In: Grazing research: design, methodology and analysis. Marten, G. C., ed. Crop Science Society of America, Madison.

Camargo, D. G.; Rocha, M. G.; Kozloski, G. V.; Elejalde, D. G.; Bremm, C.; Pötter, L.; Rosa, A. T. N. and Oliveira Neto, R. A. 2009. Consumo de forragem por cordeiras suplementadas em pastagem de milheto. Ciência Rural 39:509-514.

Campbell, A. G. 1966. Grazed pasture parameters. I. Pasture drymatter production and availability in a stocking rate and grazing management experiment with dairy cows. Journal of Agricultural Science 67:199-210. 
Carvalho, S.; Brochier, M. A.; Pivato, J.; Teixeira, R. C. and Kieling, R. 2007. Ganho de peso, características da carcaça e componentes não-carcaça de cordeiros da raça Texel terminados em diferentes sistemas alimentares. Ciência Rural 37:821-827.

Clark, D. A. and Woodward, S. L. 2007. Supplementation of dairy cows, beef cattle and sheep grazing pasture. p.117-131. In: Pasture and supplements for grazing animals. 14th ed. Rattray, P. V.; Brookes, I. M. and Nicol, A. M., eds. New Zealand Society of Animal Production, Hamilton.

EMBRAPA - Empresa Brasileira de Pesquisa Agropecuária. Centro Nacional de Pesquisa Agropecuária. 1999. Sistema brasileiro de classificação de solos. EMBRAPA, Brasília.

Fernandes, M. A. M.; Monteiro, A. L. G.; Poli, C. H. E. C.; Barros, C. S.; Ribeiro, T. M. D. and Silva, A. L. P. 2008. Características das carcaças e componentes do peso vivo de cordeiros terminados em pastagem ou confinamento. Acta Scientiarum Animal Science 30:75-81.

Fernandes, S. R.; Monteiro, A. L. G.; Silva, C. J. A.; Silva, M. G. B.; Rossi Junior, P.; Souza, D. F.; Salgado, J. A. and Hentz, F. 2011. Desmame precoce e a suplementação concentrada no peso ao abate e nas características de carcaça de cordeiros terminados em pastagem. Revista Brasileira de Saúde e Produção Animal 12:527-537.

Gibb, M. J.; Huckle, C. A. and Nuthall, R. 2002. Effects of level of concentrate supplementation on grazing behaviour and performance by lactating dairy cows grazing continuously stocked grass swards. Animal Science 74:319-335.

Hodgson, J. 1990. Grazing management: science into practice. John Wiley \& Sons, New York.

Klingman, D. L.; Miles, S. R. and Mott, G. O. 1943. The cage method for determine consumption and yield of pasture herbage. Agronomy Journal 35:739-746.

Köppen, W. 1931. Grundriss der klimakunde. Walter de Gruyter, Berlin.

Moore, J. E.; Brant, M. H.; Kuncle, W. E. and Hopkins, D. I. 1999. Effects of supplementation on voluntary forage intake, diet digestibility, and animal performance. Journal of Animal Science 77(Suppl. 2):122-135.

Miller, J. E. and Horohov, D. W. 2006. Immunological aspects of nematode parasite control in sheep. Journal of Animal Science 84: E124-E132.

Mott, G. O. and Lucas, H. L. 1952. The design, conduct and interpretation of grazing trials in cultivated and improved pastures. p.1380-1385. In: Proceedings of the 6th International Grassland Congress. State College Press, State College, PA.

Napolitano, F.; De Rosa, G. and Sevi, A. 2008. Welfare implications of artificial rearing and early weaning in sheep. Applied Animal Behaviour Science 110:58-72.

NRC - National Research Council. 2007. Nutrient requirements of small ruminants: sheep, goats, cervids and new world camelids. National Academy Press, Washington, DC.

Paciullo, D. S. C.; Gomide, J. A.; Queiroz, D. S. and Silva, E. A. M. 2001. Composição química e digestibilidade in vitro de lâminas foliares e colmos de gramíneas forrageiras em função do nível de inserção no perfilho, da idade e da estação de crescimento. Revista Brasileira de Zootecnia 30:964-974.

Poli, C. H. E. C.; Monteiro, A. L. G.; Barros, C. S.; Dittrich, J. R.; Fernandes, S. R. and Carvalho, P. C. F. 2009. Comportamento ingestivo de cordeiros em três sistemas de produção em pastagem de Tifton 85. Acta Scientiarum. Animal Sciences 31:235-241.

Rattray, P. V.; Thompson, K. F.; Hawker, H. and Sumner, R. M. W. 1987. Pastures for sheep production. p.89-104. In: Livestock feeding on pasture. Nicol, A. M., ed. New Zealand Society of Animal Production, Hamilton.

Ribeiro, T. M. D.; Monteiro, A. L. G.; Prado, O. R.; Natel, A. S.; Salgado, J. A.; Piazzetta, H. L. and Fernandes, S. R. 2009. Desempenho e características das carcaças de cordeiros em quatro sistemas de produção. Revista Brasileira de Saúde e Produção Animal 10:366-378.

Silva, M. G. B.; Monteiro, A. L. G.; Silva, C. J. A.; Fernandes, S. R.; Silva, A. L. P. and Paula, E. F. E. 2011. Estratégias de desmame precoce e de suplementação concentrada no comportamento diário de cordeiros produzidos em pastagem de Tifton-85. Revista Brasileira de Saúde e Produção Animal 12:1084-1094.

Silva, M. G. B.; Monteiro, A. L. G.; Fernandes, S. R.; Silva, C. J. A.; Cruz, T. A.; Salgado, J. A.; Kowalski, L. H. and Costa, C. 2012. Desmame precoce e a suplementação com alimentos concentrados de cordeiros e seu efeito sobre as caracerísticas morfológicas da pastagem e o consumo de forragem. Revista Portuguesa de Ciências Veterinárias 111:57-62.

Van Soest, P. J.; Robertson, J. B. and Lewis, B. A. 1991. Methods for dietaryfiber, neutral detergentfiber, and no starchpolysaccharides in relationto animal nutrition. Journal of Dairy Science 74:3583-3597.

Weiss, W. P.; Conrad, H. R. and St. Pierre, N. R. 1992. A theoreticallybased model for predicting total digestible nutrient values of forages and concentrates. Animal Feed Science and Technology 39:95-110. 